\title{
Further analysis of previously implicated linkage regions for Alzheimer's disease in affected relative pairs
} Elin S Blom¹, Vilmantas Giedraitis ${ }^{1}$, Sampath Arepalli², Marian L Hamshere ${ }^{3}$, Omanma Adighibe ${ }^{2}$, Alison Goate ${ }^{4}$, Julie Williams ${ }^{3}$, Lars Lannfelt ${ }^{1}$, John Hardy², Fabienne Wavrant-De Vrièze ${ }^{2}$ and Anna Glaser*1

\begin{abstract}
Address: ${ }^{1}$ Section of Molecular Geriatrics, Department of Public Health and Caring Sciences, Uppsala University, Uppsala, Sweden, ${ }^{2}$ Laboratory of Neurogenetics, National Institute of Aging, National Institute of Health, Bethesda, MD, USA, ${ }^{3}$ Department of Psychological Medicine \& Biostatistics and Bioinformatics Unit, Wales School of Medicine, Cardiff University, Cardiff, UK and ${ }^{4}$ Department of Psychiatry, Washington University School of Medicine, St. Louis, MO, USA

Email: Elin S Blom - elin.blom@pubcare.uu.se; Vilmantas Giedraitis - vilmantas.giedraitis@pubcare.uu.se; Sampath Arepalli - arepalli@grc.nia.nih.gov; Marian L Hamshere - hamshereml@Cardiff.ac.uk;

Omanma Adighibe - omanma.adighibe@stx.ox.ac.uk; Alison Goate - goate@icarus.wustl.edu; Julie Williams - williamsj@Cardiff.ac.uk; Lars Lannfelt - lars.lannfelt@pubcare.uu.se; John Hardy - j.hardy@ion.ucl.ac.uk; Fabienne Wavrant-De Vrièze - wavrant@mail.nih.gov; Anna Glaser* - anna.glaser@pubcare.uu.se

* Corresponding author
\end{abstract}

Published: I December 2009

BMC Medical Genetics 2009, 10:122 doi:10.1 186/147|-2350-10-122
Received: 20 April 2009

Accepted: I December 2009

This article is available from: http://www.biomedcentral.com/I47/-2350/I0/I22

(c) 2009 Blom et al; licensee BioMed Central Ltd.

This is an Open Access article distributed under the terms of the Creative Commons Attribution License (http://creativecommons.org/licenses/by/2.0), which permits unrestricted use, distribution, and reproduction in any medium, provided the original work is properly cited.

\begin{abstract}
Background: Genome-wide linkage studies for Alzheimer's disease have implicated several chromosomal regions as potential loci for susceptibility genes.

Methods: In the present study, we have combined a selection of affected relative pairs (ARPs) from the UK and the USA included in a previous linkage study by Myers et al. (Am J Med Genet, 2002), with ARPs from Sweden and Washington University. In this total sample collection of 397 ARPs, we have analyzed linkage to chromosomes I, 9, 10, 12, 19 and 21, implicated in the previous scan.

Results: The analysis revealed that linkage to chromosome $19 q 13$ close to the APOE locus increased considerably as compared to the earlier scan. However, linkage to chromosome 10q21, which provided the strongest linkage in the previous scan could not be detected.

Conclusion: The present investigation provides yet further evidence that $19 q \mid 3$ is the only chromosomal region consistently linked to Alzheimer's disease.
\end{abstract}

\section{Background}

Alzheimer's disease (AD) is the most common form of dementia and the number of affected individuals rises dramatically with an aging population. Age is the most prominent risk factor, but genetics is also important for the risk of developing AD. Three genes are known to cause autosomal dominant early-onset $\mathrm{AD}$ : the amyloid beta precursor protein $(A P P)$ on chromosome 21 [1], presenilin 1 (PSEN1) on chromosome 14 [2] and presenilin 2 (PSEN2) on chromosome 1 [3]. For the much more common sporadic $\mathrm{AD}$ with later onset, apolipoprotein $\mathrm{E}$ (APOE) on chromosome 19q13 is so far the only identi- 
fied susceptibility gene with consistently demonstrated association [4].

The $\varepsilon 4$ allele of $A P O E$ is estimated to account for less than a third of the lifetime risk for $\mathrm{AD}[5,6]$ and simulation studies have predicted at least four additional genetic loci contributing to age at onset [7]. Although such calculations are by necessity based on certain assumptions, they support the possibility that there are more genetic susceptibility factors for AD to be identified. Genome-wide linkage studies using affected sib-pairs or families have implicated a number of chromosomal loci to hold susceptibility genes [8-14]. Regions on chromosomes 9, 10, 12 and 19 seem to be the most replicated, although the exact position of the peaks can differ substantially.

In the present study, we have combined a selection of affected relative pairs (ARPs) from the UK and the USA included in an earlier linkage study by Myers et al. [10]. We have modified the original sample collection by excluding the NIMH sample and samples with ambiguous phenotypes, as well as by adding sample collections from Sweden and Washington University. We have analyzed linkage to regions on chromosomes 1, 9, 10, 12, 19 and 21 , previously implicated in the study by Myers et al.

\section{Methods \\ Samples}

A total of 580 individuals from 261 families affected by late onset $\mathrm{AD}$ (family mean age at onset $\geq 60$ years) divided into 397 ARPs were analyzed in this study. Out of these, 116 ARPs were collected in Sweden, 87 ARPs in the UK and 194 ARPs in the USA (Indiana Alzheimer Disease Center National Cell Repository and Washington University, St. Louis, MO) (Table 1).

The ARPs were selected from families where at least one relative pair was diagnosed with possible, probable or definite AD according to NINCDS-ADRDA diagnostic criteria [15]. All available family members, including unaffected relatives, were sampled and genotyped after informed consent had been collected from each participating individual or next of kin. Only Caucasian families were included to reduce potential genetic heterogeneity. This study was approved by local and national ethics committees.

Samples from the UK and the Indiana Alzheimer Disease Center National Cell Repository were also included in the study by Myers et al. To improve power of the present study, samples with ambiguous phenotypes were removed and new samples were added. This resulted in a total of 244 affected individuals from the UK and USA samples (129 ARPs) that were also genotyped in the study by Myers $e t$ al. but with another microsatellite marker set. Twelve of the families from Sweden were analyzed in Giedraitis et al. 2006 [16]. There is also a likely overlap with the Swedish samples used in the present study and the sample collection used by Sillén et al. $[13,14]$, but the extent of this overlap is unknown to us.

\section{Genotyping}

A total of 100 microsatellite markers on chromosomes 1, $9,10,12,19$ and 21 also used in a study by Blacker $e t a l$. [8] were included. The markers had an average spacing of $9.4 \mathrm{cM}$ and an average genotyping success rate of $86 \%$ (Table 2 and Additional file 1). In addition, APOE was included as a genetic marker. Data from an additional 170 microsatellite markers located on other chromosomes and with an average genotyping success rate of $<80 \%$ were included in the analysis of family structure, but not in the linkage analysis.

Amplification of the microsatellite markers was performed by multiplex PCR and the resulting fragments were separated according to size on an ABI PRISM 3700 (Applied Biosystems, Foster City, CA, USA). For quality control, each run included two CEPH samples (1331-01 and 1331-02) [17] and two water samples.

The Genotyper software v3.7 (Applied Biosystems) was used for allele calling. Marker order and intermarker distances were obtained from the Marshfield reference map [18]. APOE genotyping was performed at the respective research center.

Table I: Sample information

\begin{tabular}{|c|c|c|c|c|c|c|c|c|}
\hline Sample & PED & IND & AIND & ASP & ACP & APOE $\varepsilon 4+$ & APOE $\varepsilon 4-$ & $\mathrm{AAO} \pm \mathrm{SD}$ \\
\hline SWE & 52 & 168 & 130 & 102 & 14 & 87 & 10 & $69.1 \pm 6.2$ \\
\hline UK & 70 & 148 & 148 & 87 & 0 & 51 & 16 & $75.0 \pm 5.9$ \\
\hline USA & 139 & 369 & 302 & $|9| *$ & 3 & 143 & 16 & $72.6 \pm 6.1$ \\
\hline Total & 261 & 685 & 580 & 380 & 17 & 281 & 42 & $72.4 \pm 5.5$ \\
\hline
\end{tabular}

PED: number of pedigrees, IND: number of genotyped individuals, AIND: number of genotyped affected individuals, ASP: number of genotyped affected sib-pairs, ACP: number of genotyped pairs of affected first cousins, APOE $\varepsilon 4+$ t: number of ARPs where both individuals have at least one $A P O E \& 4$ allele, APOE $\varepsilon 4$-: number of ARPs where neither individual has an APOE $\varepsilon 4$ allele, AAO: age at onset, SD: standard deviation. * Including one half-sib pair. 
Table 2: Microsatellite marker information

\begin{tabular}{lccc}
\hline Chromosome & Number of microsatellite markers & Average intermarker distance (cM) & Genotyping success rate (\%) \\
\hline 1 & 31 & 8.9 & 86.8 \\
9 & 15 & 10.7 & 85.0 \\
10 & 20 & 8.8 & 85.0 \\
12 & 18 & 9.4 & 86.0 \\
19 & 10 & 10.1 & 85.8 \\
21 & 6 & 11.0 & 85.7 \\
\hline TOTAL & 100 & 9.4 & 85.8 \\
\hline
\end{tabular}

\section{Statistical analysis}

Family structures were verified through the Graphical relationship representation software (GRR) [19]. Mendelian errors were identified and allele frequencies for selected microsatellite markers were calculated including all available individuals using the MENDEL v8.0 software [20]. Allele frequencies were calculated for the total sample as well as for each of the analyzed subgroups: SWE, UK USA, APOE $\varepsilon 4+$ (ARPs where both individuals have at least one $A P O E \varepsilon 4$ allele), and APOE $\varepsilon 4$ - (ARPs where neither individual has an $A P O E \varepsilon 4$ allele). File conversion was performed using Mega v4.0 [21].

Allele sharing multipoint LOD scores (MLS) and twopoint LOD scores (TLS) were calculated for all groups using the Allegro v2.0 software [22]. As suggested by the software authors, an exponential model with scoring function $S_{\text {pairs }}$ and family weighting option "power: 0.5 " was used. Significance levels of detected MLSs in the total sample and the analyzed subgroups were simulated through 1000 replications using the actual data set from the selected chromosomes.

\section{Results}

In order to ensure high quality of the data included in the analysis, the GRR program was used on all available genotypes, including data from 270 microsatellite markers. This prompted us to exclude samples which displayed deviations from the expected average allele sharing between sibs or other family members. Having performed this quality check, 580 affected individuals from 261 pedigrees remained and were included in the analyses (Table 1).

The focus of this study was to further explore previously implicated linkage peaks from a genome scan by Myers et al. [10]. Both studies include samples from the UK and USA, whereas the NIMH sample used in Myers et al. was not included in the present scan, and samples from Sweden and Washington University were added. Using this modified sample collection, linkage to chromosomes 1, 9,
$10,12,19$ and 21 was analyzed in the whole sample and in subgroups based on sample origin or APOE $\varepsilon 4$ status.

Chromosome 19q13 demonstrated the highest MLS of 3.0 in the total sample, increasing to 8.3 in the APOE $\varepsilon 4+$ subsample. Chromosome 1 p36 revealed an MLS of 3.5 in the UK subgroup and chromosome 10p15 showed an MLS of 2.4 in the APOE 84 - subgroup. The region spanning chromosome $10 \mathrm{q} 22-25$ showed MLSs of 1.3, 1.8 and 1.9 in the total sample, the APOE $\varepsilon 4$ - and the USA subgroups, respectively (Table 3 ). Results from this linkage analysis have been depicted in Figure 1 with the positions of linkage peaks from Myers et al. denoted for comparison.

Using data from the selected chromosomes, significance threshold levels were simulated for the total samples, as well as for the respective subgroups. After this simulation, linkage to chromosomes $19 \mathrm{q} 13$ in the total sample and the APOE $\varepsilon 4+$ subgroup and to $1 \mathrm{p} 36$ in the UK subgroup are considered significant according to the definition by Lander and Kruglyak [23] (Table 3).

\section{Discussion}

In the past decade there have been a number of attempts at identifying $\mathrm{AD}$ linkage regions using affected sib-pairs or extended families [8-14]. Although results have varied considerably and have sometimes been difficult to replicate, the most convincing linkage peaks have been reported from chromosomes 9, 10, 12, and 19 .

In the present study, linkage peaks on chromosomes 1, 9, $10,12,19$ and 21, previously implicated in a whole genome scan by Myers et al. have been further analyzed using a modified version of the original sample with an added collection of ARPs from Sweden and Washington University. We could detect significant linkage to chromosome $19 \mathrm{q} 13$ in the immediate vicinity of the APOE locus. This linkage peak was noticeably increased from the scan by Myers et al. and the Swedish sample contributed considerably to the improved linkage (Table 3 ). The influence of the APOE locus on AD has been correlated to a lower 

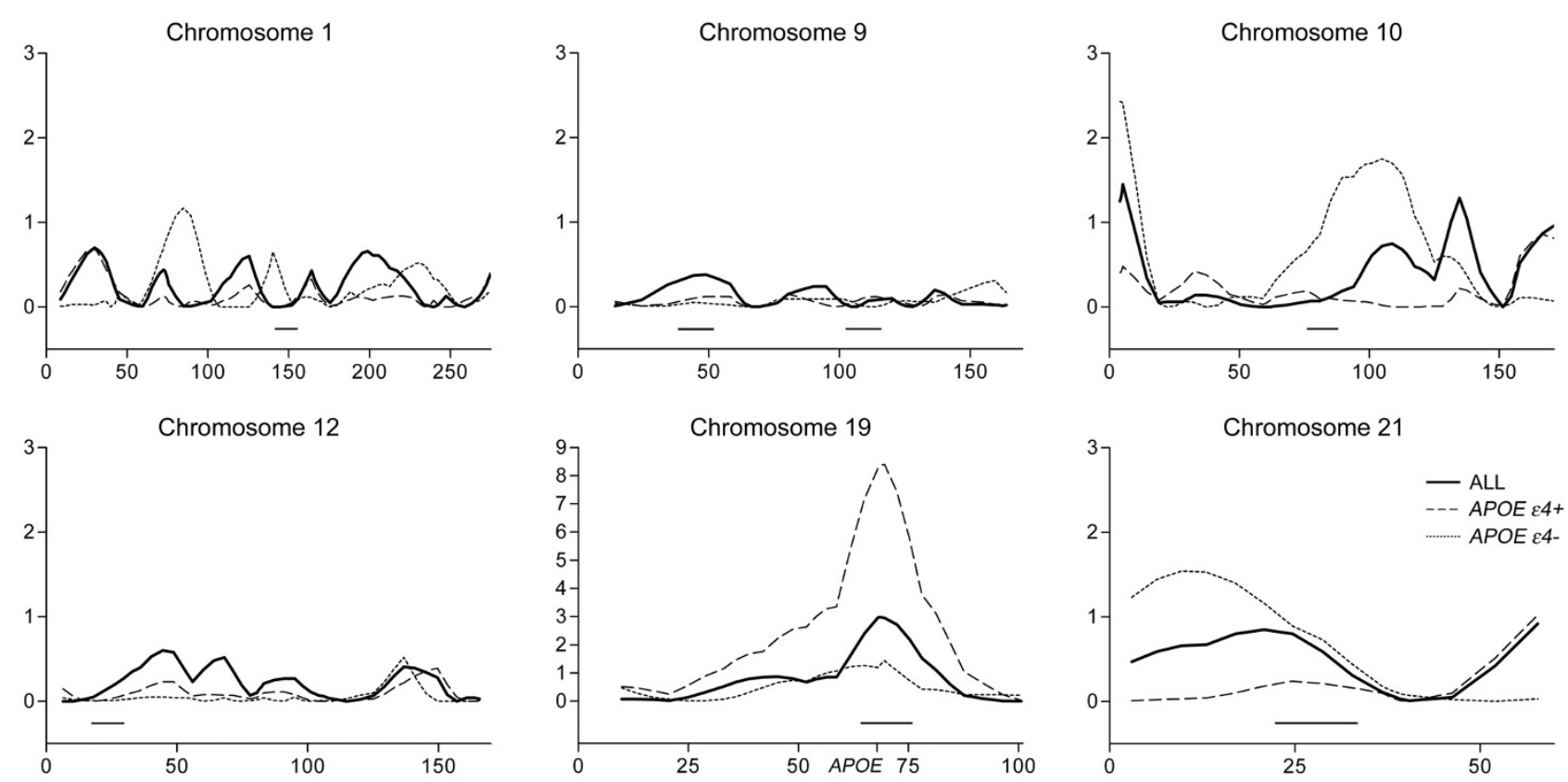

Figure I

Linkage results. Linkage across selected chromosomes in the whole sample and the APOE $\varepsilon 4+$ and APOE $\varepsilon 4-$ subgroups. $Y$ axes on all graphs represent MLS and X-axes are distance from pter in cM. MLS peaks $( \pm 5 \mathrm{cM})$ from Myers et al. are indicated below the graphs.

Table 3: Maximum MLS and (TLS) $\geq I$ from the present study

\begin{tabular}{|c|c|c|c|c|c|c|c|}
\hline Chr region & Nearest marker (cM) & ALL & SWE & UK & USA & APOE $\varepsilon 4+$ & APOE $\varepsilon 4-$ \\
\hline Ip36 & DIS3669 (37) & - & - & $3.5^{\mathrm{b}}\left(3.3^{\mathrm{b}}\right)$ & - & - & - \\
\hline Ip32 & DIS3728 (85) & - & - & - & - & - & 1.2 \\
\hline $10 p 15$ & DIOSI2I8 (5) & $1.5^{\mathrm{a}}$ & - & - & $1.5^{\mathrm{a}}$ & - & $2.4^{\mathrm{a}}(1.3)$ \\
\hline $10 q 22$ & DIOS2327 (105) & - & - & - & - & - & $1.8^{\mathrm{a}}$ \\
\hline $10 q 25$ & DIOSI237 (135) & I.3 (I.I) & - & - & $1.9^{a}(1.4)$ & - & - \\
\hline $10 q 26$ & DIOS2I2 (I7I) & $(1.2)$ & - & - & 1.1 & - & - \\
\hline $12 q 13$ & DI2S398 (68) & $\left(1.5^{a}\right)$ & I.3 (I.4) & - & - & - & - \\
\hline $12 q 23$ & $\mathrm{PAH}(109)$ & - & $1.1(1.3)$ & - & - & - & - \\
\hline $12 q 24$ & DI2S395 (137) & - & - & - & 1.0 & - & $\left(1.6^{a}\right)$ \\
\hline $12 q 24$ & DI2S392 (I66) & - & 1.1 & - & - & - & - \\
\hline $19 p 13$ & DI9S586 (36) & - & $1.7^{\mathrm{a}}$ & - & - & 1.5 & - \\
\hline $19 q 13$ & DI9SI78 (68) & $3.0^{\mathrm{b}}\left(2.5^{\mathrm{b}}\right)$ & $1.9^{a}\left(1.6^{a}\right)$ & - & I.I & $8.3^{b}\left(7.3^{b}\right)$ & 1.2 \\
\hline $2|q 2|$ & D2ISI437 (I3) & - & - & - & - & - & $1.5^{\mathrm{a}}\left(1.6^{\mathrm{a}}\right)$ \\
\hline $21 \mathrm{~g} 22$ & D2ISI 446 (58) & (1.3) & - & - & - & $1.0(1.2)$ & - \\
\hline
\end{tabular}

Within each linkage region, the marker closest to the highest MLS has been denoted with its position in cM. Threshold levels were estimated from simulation analysis of the selected chromosomes. aSuggestive and bsignificant linkage for the respective linkage region and sample group according to Lander and Kruglyak [23]. 
age at onset $[4,24]$, as further demonstrated in our recent analysis of the chromosome 19 linkage [25]. Accordingly, linkage analysis of the NIMH cohort by Blacker et al. demonstrated the highest linkage to chromosome 19q13 in their subsample with earlier disease onset, whereas no linkage to this region was detected in their late onset sample [8]. The only other significant linkage found in the present study was to chromosome 1p36 in the UK subsample. However, this peak was neither detected in the other subgroups, nor in the total sample.

In the original whole genome scan by Myers et al., the most significant linkage peak was demonstrated on chromosome 10q21 (82 cM) in the whole sample. Blacker et al. also found linkage in the region, to chromosome 10 q22 (92 cM) in their total collection of NIMH samples. In the present study, we could not detect linkage to chromosome $10 \mathrm{q} 21$, even though a suggestive linkage of MLS 1.8 was detected to chromosome $10 \mathrm{q} 22$ (105 cM) in the APOE $\varepsilon 4$ - sample. Although the sample size in the present study is smaller than in the study by Myers et al. (380 and 451 ASPs, respectively), the previous study by Kehoe et al. [9] using 292 ASPs and including overlapping samples with the Myers study also detected linkage to chromosome $10 \mathrm{q} 21$. This suggests that the absence of a linkage peak on chromosome 10q21 in the present study might be due to sample differences between the studies rather than sample size. However, we cannot completely exclude that our linkage to chromosome $10 \mathrm{q} 22$ in the APOE $\varepsilon 4$ subsample coincides with the previously detected linkage to chromosome 10q21-22, although the positions of these peaks differ by $13-23 \mathrm{cM}$. Certain caution is also called for as the APOE $\varepsilon 4$ - subsample is rather limited in size (42 ARPs).

Inconsistent results between linkage studies might reflect heterogeneity in sample cohorts, including age at onset, ethnic background and diagnostic criteria. Our finding of significant linkage to chromosome $19 q 13$, but to no other regions in the total sample in combination with the results presented by Blacker et al., suggests that finding significant linkage to both chromosome 19 q13 and additional regions in the same sample is uncommon.

In the past few years, whole genome association studies have successfully identified susceptibility loci for a number of complex conditions. However, $A P O E$ is so far the only locus demonstrating strong association to AD [26-28]. Sample sizes have turned out to be crucial and sample collections including thousands of cases have been analyzed for association [29]. Increasing the number of samples in analyses also of ARPs would most likely be beneficial for the outcome and therefore further efforts to combine different sample collections should be made. It has been suggested that data from linkage analysis of affected sib-pairs could also be used to verify candidate susceptibility genes from association studies, since the frequency of a risk allele is expected to be higher in siblings sharing the locus than in population based cases [30].

\section{Conclusion}

In this linkage study, we have analyzed a sample collection of AD ARPs from Sweden, the UK and the USA for linkage to chromosomes 1, 9, 10, 12, 19 and 21, implicated in the previous study by Myers et al. [10]. The highest linkage was detected on chromosome 19q13 close to the APOE gene. This linkage was extensively contributed by the Swedish samples, which has a lower average age at onset than the other subgroups. There was no evidence of the previously demonstrated linkage to chromosome 10q21 in the whole sample collection, and the relevance of the suggestive linkage within the APOE $\varepsilon 4$ - subgroup to chromosome 10q22 is somewhat uncertain due to the altered position of the peak and the restriction to this subgroup only. Our study demonstrates that chromosome 19 q13 including $A P O E$, at this point, is the only consistently linked locus for AD. This is also supported by genome wide association studies, demonstrating that $A P O E$ is the major susceptibility gene for AD [26]. Any additional susceptibility loci for AD are therefore likely to have much smaller effects, demanding very large sample sizes for detection.

\section{Competing interests}

The authors declare that they have no competing interests.

\section{Authors' contributions}

ESB carried out the genotyping, compiled data and participated in drafting the manuscript; VG carried out the statistical analyses; SA participated in the genotyping; MLH participated in creating the pedigree file; OA participated in the genotyping; A. Goate and JW participated in the design of the study; LL conceived the study and participated in its design and coordination; JH conceived the study, participated in its design and coordination, and revised the manuscript; FWDV participated in the genotyping and in designing and coordinating the study; A. Glaser participated in designing and coordinating the study and in drafting the manuscript. All authors read and approved the final manuscript.

\section{Additional material}

\section{Additional file 1}

Chromosomal positions of markers included in the scan. This word DOC contains a table displaying chromosomal positions of markers included in the scan.

Click here for file

[http://www.biomedcentral.com/content/supplementary/14712350-10-122-S1.DOC] 


\section{Acknowledgements}

The authors wish to thank all the participating families and everyone involved in collecting samples. The Swedish work was supported by The Swedish Research Council, The Swedish Alzheimer foundation, APOPIS (Contract No. LSHM-CT-2003-503330), and NIH grant number ROI AG08724. The UK group was supported by funding from the Alzheimer's Research Trust and the Medical Research Council. The USA samples were collected with support from the NIA/NIH intramural research program and grants numbers UOI MH4628I, UOI MH46290, UOI MH46373 (NIMH), U24 AG2I 886 (NCRAD), and AGI 6208 (AG).

\section{References}

I. Goate A, Chartier-Harlin MC, Mullan M, Brown J, Crawford F, Fidani L, Giuffra L, Haynes A, Irving N, James L, et al.: Segregation of a missense mutation in the amyloid precursor protein gene with familial Alzheimer's disease. Nature 1991, 349(63 I I):704-706.

2. Sherrington R, Rogaev El, Liang Y, Rogaeva EA, Levesque G, Ikeda M, Chi H, Lin C, Li G, Holman K: Cloning of a gene bearing missense mutations in early-onset familial Alzheimer's disease. Nature 1995, 375(6534):754-760.

3. Levy-Lahad E, Wasco W, Poorkaj P, Romano DM, Oshima J, Pettingell WH, Yu CE, Jondro PD, Schmidt SD, Wang K, et al.: Candidate gene for the chromosome I familial Alzheimer's disease locus. Science 1995, 269(5226):973-977.

4. Corder EH, Saunders AM, Strittmatter WJ, Schmechel DE, Gaskell PC, Small GW, Roses AD, Haines JL, Pericak-Vance MA: Gene dose of apolipoprotein $E$ type 4 allele and the risk of Alzheimer's disease in late onset families. Science 1993, 26 I (5 I 23):921-923.

5. Seshadri S, Drachman DA, Lippa CF: Apolipoprotein E epsilon 4 allele and the lifetime risk of Alzheimer's disease. What physicians know, and what they should know. Arch Neurol 1995, 52(I I): 1074-1079.

6. Slooter AJ, Cruts M, Kalmijn S, Hofman A, Breteler MM, Van Broeckhoven C, van Duijn CM: Risk estimates of dementia by apolipoprotein $E$ genotypes from a population-based incidence study: the Rotterdam Study. Arch Neurol 1998, 55(7):964-968.

7. Daw EW, Payami H, Nemens EJ, Nochlin D, Bird TD, Schellenberg GD, Wijsman EM: The number of trait loci in late-onset Alzheimer disease. Am J Hum Genet 2000, 66(I): I96-204.

8. Blacker D, Bertram L, Saunders AJ, Moscarillo TJ, Albert MS, Wiener H, Perry RT, Collins JS, Harrell LE, Go RC, et al.: Results of a highresolution genome screen of 437 Alzheimer's disease families. Hum Mol Genet 2003, I 2(I):23-32.

9. Kehoe P, Wavrant-De Vrieze F, Crook R, Wu WS, Holmans P, Fenton I, Spurlock G, Norton N, Williams H, Williams N, et al.: A full genome scan for late onset Alzheimer's disease. Hum Mol Genet 1999, 8(2):237-245.

10. Myers A, Wavrant De-Vrieze F, Holmans P, Hamshere M, Crook R, Compton D, Marshall H, Meyer D, Shears S, Booth J, et al.: Full genome screen for Alzheimer disease: stage II analysis. Am J Med Genet 2002, I I 4(2):235-244.

II. Pericak-Vance MA, Bass ML, Yamaoka LH, Gaskell PC, Scott WK, Terwedow HA, Menold MM, Conneally PM, Small GW, Saunders AM, et al: Complete genomic screen in late-onset familial Alzheimer's disease. Neurobiol Aging 1998, I 9(I Suppl):S39-42.

12. Pericak-Vance MA, Grubber J, Bailey LR, Hedges D, West S, Santoro L, Kemmerer B, Hall JL, Saunders AM, Roses AD, et al.: Identification of novel genes in late-onset Alzheimer's disease. Exp Gerontol 2000, 35(9-10): I343-I352.

13. Sillén A, Andrade J, Lilius L, Forsell C, Axelman K, Odeberg J, Winblad B, Graff C: Expanded high-resolution genetic study of 109 Swedish families with Alzheimer's disease. Eur J Hum Genet 2008, I 6(2):202-208.

14. Sillén A, Forsell C, Lilius L, Axelman K, Bjork BF, Onkamo P, Kere J, Winblad B, Graff C: Genome scan on Swedish Alzheimer's disease families. Mol Psychiatry 2006, I I(2): I82-I86.

15. McKhann G, Drachman D, Folstein M, Katzman R, Price D, Stadlan EM: Clinical diagnosis of Alzheimer's disease: report of the NINCDS-ADRDA Work Group under the auspices of Department of Health and Human Services Task Force on Alzheimer's Disease. Neurology 1984, 34(7):939-944.
16. Giedraitis V, Hedlund M, Skoglund L, Blom E, Ingvast S, Brundin R, Lannfelt L, Glaser A: New Alzheimer's disease locus on chromosome 8. J Med Genet 2006.

17. Dausset J, Cann H, Cohen D, Lathrop M, Lalouel JM, White R: Centre d'etude du polymorphisme humain (CEPH): collaborative genetic mapping of the human genome. Genomics 1990 , 6(3):575-577.

18. Broman KW, Murray JC, Sheffield VC, White RL, Weber JL: Comprehensive human genetic maps: individual and sex-specific variation in recombination. Am J Hum Genet 1998, 63(3):86I-869.

19. Abecasis GR, Cherny SS, Cookson WO, Cardon LR: GRR: graphical representation of relationship errors. Bioinformatics 200I, I 7(8):742-743.

20. Lange K, Cantor R, Horvath S, Perola M, Sabatti C, Sinsheimer J, Sobel E: Mendel version 4.0: A complete package for the exact genetic analysis of discrete traits in pedigree and population data sets. Amer J Hum Genetics 200I, 69(supplement):Al886.

21. Mukhopadhyay N, Almasy L, Schroeder M, Mulvihill WP, Weeks DE: Mega2: data-handling for facilitating genetic linkage and association analyses. Bioinformatics 2005, 2 I ( I 0):2556-2557.

22. Gudbjartsson DF, Thorvaldsson T, Kong A, Gunnarsson G, Ingolfsdottir A: Allegro version 2. Nat Genet 2005, 37(1 0):1015-1016.

23. Lander E, Kruglyak L: Genetic dissection of complex traits: guidelines for interpreting and reporting linkage results. Nat Genet 1995, I I(3):24I-247.

24. Meyer MR, Tschanz JT, Norton MC, Welsh-Bohmer KA, Steffens DC, Wyse BW, Breitner JC: APOE genotype predicts when - not whether - one is predisposed to develop Alzheimer disease. Nat Genet 1998, I9(4):321-322.

25. Blom ES, Holmans P, Arepalli S, Adighibe O, Hamshere ML, Gatz M, Pedersen NL, Bergem AL, Owen MJ, Hollingworth P, et al.: Does APOE explain the linkage of Alzheimer's disease to chromosome I9qI3? Am J Med Genet B Neuropsychiatr Genet 2008, I47B(6):778-783.

26. Coon KD, Myers AJ, Craig DW, Webster JA, Pearson JV, Lince DH, Zismann VL, Beach TG, Leung D, Bryden L, et al.: A high-density whole-genome association study reveals that APOE is the major susceptibility gene for sporadic late-onset Alzheimer's disease. J Clin Psychiatry 2007, 68(4):6I3-618.

27. Grupe A, Abraham R, Li Y, Rowland C, Hollingworth P, Morgan A, Jehu L, Segurado R, Stone D, Schadt E, et al.: Evidence for novel susceptibility genes for late-onset Alzheimer's disease from a genome-wide association study of putative functional variants. Hum Mol Genet 2007, I 6(8):865-873.

28. Li H, Wetten S, Li L, St Jean PL, Upmanyu R, Surh L, Hosford D, Barnes MR, Briley JD, Borrie M, et al.: Candidate single-nucleotide polymorphisms from a genomewide association study of Alzheimer disease. Arch Neurol 2008, 65(I):45-53.

29. Genome-wide association study of 14,000 cases of seven common diseases and 3,000 shared controls. Wellcome Trust Case Control Consortium. Nature 2007, 447(7 | 45):66I-678.

30. Hardy J, Myers A, Wavrant-De Vrieze F: Problems and solutions in the genetic analysis of late-onset Alzheimer's disease. Neurodegener Dis 2004, I(4-5):21 3-2I7.

\section{Pre-publication history}

The pre-publication history for this paper can be accessed here:

http://www.biomedcentral.com/1471-2350/10/122/pre pub 